\title{
ARTICLES
}

\section{EXPERIENCES OF STUDENTS WITH COMMUNICATION RELATED DISABILITIES IN THE TBL CLASSROOM}

\author{
Rachel Berkson \\ Scopus Author ID: 8618196500 \\ rachel@outgra.be \\ Anglia Ruskin University, UK \\ Uwe Matthias Richter \\ ORCID: 0000-0001-6033-203X \\ uwe.richter@anglia.ac.uk \\ Anglia Ruskin University, UK \\ Sarada Veerabhatla \\ saradavn@gmail.com \\ Anglia Ruskin University, UK \\ Larysa Zasiekina \\ ORCID: 0000-0001-8456-0774 \\ Scopus Author ID: 57215414977 \\ zasyekina.larisa@eenu.edu.ua \\ Lesya Ukrainka Eastern European National University, Ukraine
}

Received March 12, 2020; Revised June 22, 2020; Accepted June 25, 2020

\begin{abstract}
The objective of this article is to explore how suitable Team-Based Learning (TBL) is for students with social and communication disabilities, such as those on the autism spectrum or with social anxiety. TBL is a structured form of Active Collaborative Learning, combining a flipped classroom approach with students working in permanent teams to apply concepts, models and theories into practice. The design of the study was based on an idiographic case study approach at Anglia Ruskin University, UK, treating each student as an individual rather than a representative sample. Towards the end of the academic year 2017/18, an electronic questionnaire was sent out to all students who had taken TBL modules at ARU during the preceding academic year, asking about various aspects of TBL experience. The questionnaire was repeated towards the end of the first semester of 2018/19. The questionnaire was analysed with a focus on questions relating to inclusivity, and the responses related to students who had declared a disability. The questionnaire was followed by semi-structured interviews with students with disabilities who had experienced TBL. We focused primarily on disabilities broadly related to communication, notably with dyslexia, dysgraphia, social phobia and autism that may impair students' abilities to work in teams. Interviews were audio recorded and then transcribed. Transcriptions were thematically analysed by the research team using
\end{abstract}

(C) Berkson, Rachel; Richter, Uwe Matthias; Veerabhatla, Sarada; Zasiekina, Larysa, 2020. This is an Open Access article distributed under the terms and conditions of the Creative Commons Attribution 4.0 International Licence (https://creativecommons.org/licenses/by/4.0/).

East European Journal of Psycholinguistics, 7(1), 7-27. https://doi.org/10.29038/eejpl.2020.7.1.ber 
NVivo. The results of the study provide anonymized case studies for each of the students who took part in an interview, explaining their disability or condition, their coping strategies for studying in $\mathrm{HE}$, and their experiences, both positive and negative, of the TBL modules they had taken.

Keywords: Team-Based Learning, Active Collaborative Learning, communication disabilities, anonymized case studies.

\section{Берксон Рейчел, Ріхтер Уве Матіас, Вірабхатла Шарада, Засскіна Лариса. Досвід командно-орієнтованого навчання студентів із особливими комунікативними проблемами.}

Анотація. Мета статті - на теоретичному і емпіричному рівні встановити ефективність командно-орієнтованого навчання $(\mathrm{KOH})$ студентів із особливими комунікативними проблемами. КОН - це вид активного колаборативного навчання студентів у командах, упродовж якого концепти, моделі і теорії втілюються у практику. У дослідженні використовується дизайн кейс стаді, у якому досвід кожного студента вивчається індивідуально без урахування репрезентативності вибірки. Наприкінці 2017-2018 навчального року студентам було запропоновано online опитування для фіксації досвіду КОН. Повторне опитування проводилося також у 2018-2019 навчальному році. Основна увага фокусувалася на питаннях інклюзії для студентів із особливими комунікативними проблемами. Після цього із цими студентами здійснювалося напів-структуроване інтерв'ю. Вибірку склали студенти, які мають особливі проблеми 3 комунікацією, зокрема читанням і письмом: студенти із дислексією i дисграфією, соціальною тривожністю та аутичним спектром. Усі ці студенти відчувають значні труднощі у роботі в команді. Інтерв'ю записувалися і транскрибувалися, а згодом піддавалися якісному аналізу із виділенням тематичних категорій 3 допомогою комп'ютерної програми NVivo. Результати дослідження дали змогу виокремити анонімні індивідуальні випадки (кейси) із визначенням природи особливих потреб упродовж комунікації, копінг стратегій упродовж навчання, а також позивного і негативного досвіду роботи у команді.

Ключові слова: командно-орієнтоване навчання, активне колаборативне навчання, комунікативні особливі потреби, індивідуальні кейси.

\section{Introduction}

Team-Based Learning (TBL) is a structured form of Active Collaborative Learning (ACL) (Sibley \& Ostafichuk, 2014), combining a flipped classroom approach with students working in permanent teams to apply concepts, models and theories into practice. The team approach means that students increasingly hold each other accountable for coming to class prepared and working together. TBL has been shown to improve performance for all, with particular benefits for lower performing students (Koles et al., 2010). TBL also develops real-world skills such as team-working and communication.

We took part in a national project, funded by the Office for Students (OfS), the independent regulator of Higher Education in England. The project aimed to improve success for students from certain minority backgrounds who often have worse outcomes in Higher Education (HE) than would be expected (Office for Students, 2019a). The project primarily focused on students from disadvantaged socio-economic and ethnic minority backgrounds. We were also interested in other groups who experience unexplained disparities in HE outcomes, including students with 
disabilities. The project was a collaboration between three diverse UK universities, Nottingham Trent University (the lead institution), University of Bradford, and our institution, Anglia Ruskin University (ARU). Over the course of the two-year project, all three institutions worked to scale up the use of ACL methods to the whole institution level, to address disparities. The form of ACL chosen at Nottingham Trent University was SCALE-UP (McNeil et al., 2019a), while ARU and Bradford used TBL.

The three universities successfully increased adoption of ACL methods (Active Collaborative Learning, 2019), and found that degree courses (programmes) that used ACL had improved attendance and performance for most groups of students compared to other courses. The effects were particularly marked where students took multiple ACL modules, and most elements of the chosen ACL approaches were applied. All three institutions saw some narrowing of performance gaps experienced by students from disadvantaged backgrounds when they moved to ACL (Berkson \& Richter, 2019; McNeil et al., 2019b).

A concern expressed by members of teaching staff involved in the project at ARU was that TBL would not be suitable for students with social and communication disabilities, such as those on the autism spectrum or with social anxiety. A high proportion of students at ARU have some form of specific learning difficulty such as dyslexia (ARU, 2018). We also observed that there was no systematic approach to inclusive practice of TBL, but rather, each practitioner adapted the methods on an adhoc basis to meet the needs of particular students. Further, many of the reasonable adjustments for students with disabilities that would be made in a traditional course (e.g. one based on lectures, seminars and terminal exams) would not be fit for purpose for TBL (Berkson Richter, 2020).

For example, many students with disabilities or specific learning difficulties related to reading and writing, require extra time in exams, but this adjustment is difficult to apply meaningfully in the context of short in-class multiple choice quizzes used in TBL, known as individual and team Readiness Assurance Tests (iRAT/tRAT) (Sibley \& Ostafichuk, 2014). Reasonable adjustments for students with some mental health conditions may involve the option to sit exams in a separate room, but doing so would mean missing out on the team engagement and the peer learning elements of the tRAT. Students who miss a summative assessment due to illness are offered resit opportunities, but there is no meaningful way to resit the iRAT/tRAT assessments because they are designed to assess completion of pre-session learning for a particular class session, and once that session has passed preparation is no longer relevant.

In our literature review, as well as in other research reviews on TBL (Dearnley, 2018; Haidet et al., 2014; Sisk, 2011), we found very little research on experiences of students with disabilities learning using TBL. We found evidence for successful approaches to the inclusion of students with disabilities is often based on school teaching, and evidence for the success of TBL mostly looks at students in the aggregate 
with no reports of differential or equivalent outcomes for students with any kind of disability (Sangwan \& Sangwan, 2011; Vaccaro et al., 2015; Vaughn et al., 2015; Wanzek, 2014). A literature search identified a single study on TBL involving students with specific learning difficulties in a secondary school classroom in the US (Kent et al., 2015).

In recent years, there has been a substantial increase in the number of students with declared disabilities studying at university (Office for Students, 2019a; Williams et al., 2019). This group of students often experiences worse outcomes than their nondisabled peers, as they have been found to be less likely to complete their programmes of study, less likely to achieve so-called "good" degrees (defined as 2:1 or First Class), and less likely to obtain graduate jobs after they leave university (Hefce, 2018). Universities have a moral responsibility to ensure that students with disabilities have a comparable educational experience to their peers.

ACL has a range of demonstrated benefits for students who learn by carrying out meaningful activities (beyond reading and listening), and who mix working in groups or teams with working individually. Most careers that graduates are likely to take up require the ability to think creatively to solve problems, work in teams, and have the capacity to learn and analyse new information (HM Government, 2017; OECD, 2019; World Economic Forum, 2018). All these skills are supported by the use of ACL. For students with disabilities to benefit from these opportunities, there is a need for research into how to adapt ACL approaches to meet the needs of all learners.

It is also important that research into the experiences of students with disabilities centres the student voice, as otherwise non-disabled researchers' bias may lead to assumptions and the imposition of their own interpretations on student experiences. To avoid bias the research instruments were tested by critical friends with backgrounds in disability support and research. (Chenail, 2009; Roulston \& Shelton, 2015). As part of the project, we carried out a study into the experiences of students with disabilities who learned with TBL at ARU, focusing particularly on in-depth interviews with individual students about their experiences. We used the interview material to create anonymised case studies. The case studies provided evidence to inform recommendations for good, inclusive classroom practice, in consultation with the Disability and Dyslexia Service at ARU. In this way, the present study started to address the gap in direct evidence for including students with disabilities in the Active Learning context.

\section{Methods}

The main approach of the study was to carry out semi-structured interviews with students with disabilities who had experienced TBL. We focused primarily on disabilities broadly related to communication. This category includes specific learning difficulties that affect reading and writing, such as dyslexia and dysgraphia; sensory disabilities such as hearing and visual impairments; mental health conditions that may affect students' experiences in the active classroom; and finally social disabilities such 
as autism, that may impair students' abilities to work in teams. Many of the students in our study reported multiple disabilities, such as a specific learning difficulty coexisting with a mental health condition.

Our definition of disability relied exclusively on student self-declaration. Many students formally declare a disability to the university in order for their disability to be recognised and to access support and entitlements to reasonable adjustments (ARU, 2020a), either when they start their courses or at some point during their studies. However, it is very likely that some students who have a disability have not declared it.

We used semi-structured interviews to probe further into the findings of an earlier mixed methods study, to determine whether TBL is an effective and inclusive approach for students with disabilities. The earlier research involved analysing quantitative data, obtained from the student records system, on student attendance, engagement, satisfaction and performance for students learning with TBL or in modules on related courses that did not use TBL, and tested whether there were gaps in achievement between disabled and non-disabled students. Students' declared disabilities were classified into broad categories such as "physical or mobility disability", "chronic illness", "mental health condition", "social or communication disability", "specific learning difficulty". For ethical reasons, we did not obtain medically sensitive information on the exact nature of students' disabilities or conditions.

Towards the end of the academic year 2017/18, an electronic questionnaire was sent out to all students who had taken TBL modules during the preceding academic year, asking about various aspects of TBL experience. The questionnaire was repeated towards the end of the first semester of 2018/19 to capture responses for the new academic year. Completion of the questionnaire was voluntary. We analysed the questionnaire findings with a focus on questions relating to inclusivity and noted the responses of students who had declared a disability.

In early 2019, we carried out semi-structured interviews with students with disabilities who had learned using TBL during the academic year 2018/9. We invited all students from TBL courses to attend interviews if they had a disability and offered a small financial incentive ( $£ 10$ Amazon vouchers) to compensate participants for their time. Students who volunteered to be interviewed informed the interviewer about their disabilities. We based our analysis on students' own self-conception and narrative of their identity and situation. Interviews were audio-recorded and then transcribed. Transcriptions were thematically analysed by the research team using NVivo.

The design of the study was based on an idiographic case study approach, treating each student as an individual rather than a representative sample. This aligned with our philosophy of centring disabled voices. We created anonymized case studies for each of the students who took part in an interview, explaining their disability or condition, their coping strategies for studying in HE, and their experiences, both positive and negative, of the TBL modules they had taken. 


\section{Results}

\subsection{The study population}

Automated data was obtained for the following students (Table 1).

Table 1

Number of students taking TBL module

\begin{tabular}{llll}
\hline Year & $\begin{array}{l}\text { Number of students } \\
\text { who took at least one } \\
\text { TBL module }\end{array}$ & $\begin{array}{l}\text { Number of students on } \\
\text { related courses who } \\
\text { did not take any TBL } \\
\text { modules }\end{array}$ & $\begin{array}{l}\text { Total number of } \\
\text { students included in } \\
\text { the analysis }\end{array}$ \\
\hline $2015 / 6$ & 1,654 & 5,146 & 6,800 \\
$2016 / 7$ & 3,022 & 3,987 & 7,009 \\
$2017 / 8$ & 2,220 & 4,718 & 6,938 \\
\hline
\end{tabular}

We did not have permission to obtain detailed automated data for the academic year 2018/9. Note that the same student is likely to appear in multiple years of the study, as they would have progressed through their course during the period under investigation. For comparisons to be meaningful and to account for cohort variation, data was analysed separately for each of the three years of the study.

The proportion of students with declared disabilities was similar among the group who took TBL modules and the group who studied on related courses but did not take TBL modules (Table 2).

Table 2

Number of disabled students taking TBL module

\begin{tabular}{llllll}
\hline Year & $\begin{array}{l}\text { Number of TBL } \\
\text { students } \\
\text { declared } \\
\text { disabilities }\end{array}$ & $\begin{array}{l}\text { Proportion of } \\
\text { disabled } \\
\text { students } \\
\text { taking } \\
\text { modules }\end{array}$ & $\begin{array}{l}\text { Number of non- } \\
\text { TBL students on disabled } \\
\text { related courses students who } \\
\text { with declared did not take } \\
\text { disabilities }\end{array}$ & $\begin{array}{l}\text { did } \\
\text { TBL modules }\end{array}$ \\
\hline $2015 / 6$ & 183 & $11 \%$ & 816 & $16 \%$ \\
$2016 / 7$ & 663 & $22 \%$ & 639 & $16 \%$ \\
$2017 / 8$ & 313 & $14 \%$ & 695 & $15 \%$ \\
\hline
\end{tabular}

In all years, the most common declared disability was a specific learning difficulty such as dyslexia or dysgraphia, representing about half the students who declared any disability. Outcomes for students who declared disabilities were comparable to outcomes for students without declared disabilities. 
The measured disparities between students with and without declared disabilities in our study were generally small. This is in line with the broader picture at ARU where multiple interventions have been put in place to support disabled students and implement inclusive practice, leading to a year-on-year narrowing of the attainment gap between students with and without disabilities, to the point where there was no significant difference in attainment between the two groups of students in the academic year ending 2017 (ARU, 2017).

In general, we found that students with declared disabilities had slightly lower attendance and engagement than students with no recorded disability. Students with disabilities also received slightly lower average module marks (a difference of less than 5 percentage points in most cases), and correspondingly slightly lower average course marks. These already small gaps were smaller in TBL modules than non-TBL modules on related courses and smaller for graduates who experienced at least one TBL module during their courses compared to graduates who did not experience any TBL. In 2018, the good degree attainment gap for disability was 7 percentage points for students who had not experienced TBL, compared to 3 percentage points for students who had taken at least one module during the three years of their course.

\subsection{Impact of TBL on students with different categories of disability}

The numbers of students with some categories of disability were very small. This means that it is not statistically meaningful to make detailed comparisons of outcomes between groups. We, therefore, chose to report the direction and rough magnitude of differences in outcomes depending on whether students learned using TBL, rather than the exact figures. Caution should be exercised in interpreting these findings, which refer to small groups of students (Table 3).

Table 3

Types of students' disabilities

\begin{tabular}{|c|c|c|c|}
\hline Type of disability & $2015 / 6$ & 2016/7 & $2017 / 8$ \\
\hline Chronic illness & + & + & - \\
\hline Mental health condition & - & 0 & 0 \\
\hline $\begin{array}{l}\text { Physical impairment or mobility } \\
\text { issues }\end{array}$ & + & ++ & - \\
\hline Social/communication impairment & 0 & ++ & + \\
\hline Specific learning difficulty & 0 & + & 0 \\
\hline $\begin{array}{l}\text { Blind or a serious visual } \\
\text { impairment }\end{array}$ & 0 & + & + \\
\hline $\begin{array}{l}\text { Deaf or a serious hearing } \\
\text { impairment }\end{array}$ & - & + & - \\
\hline Other & + & + & - \\
\hline Two or more disabilities & + & + & ++ \\
\hline
\end{tabular}

Key: Differences in outcomes $+/++$ improved, 0 - stayed the same, $-/$ — worsened 
Broadly, we found that for most categories of disability, marks improved in TBL modules compared to non-TBL modules. In particular, we observed relatively large improvements in marks for students with social or communication disabilities, such as autism, in TBL modules. This finding challenges the frequent assumption that students on the autism spectrum "can't do group work"; our data imply that the autistic students who took TBL modules during the period of the study benefited from this learning and teaching approach. However, the category of social or communication disabilities may include conditions other than autism spectrum disorders, as well as relatively mild impairments.

We did not observe clear benefits of TBL for students with hearing impairments. The number of students who declared a hearing impairment or hearing loss is admittedly very small, but our findings indicated that marks were lower for TBL modules compared to non-TBL modules. This is an area of concern for inclusive practice; it is possible that the often noisy environment of multiple team discussions in parallel in the same room may be less conducive for the learning of students with hearing impairments.

\subsection{Student questionnaire findings}

Student surveys were sent to 3,587 students, and responses were received from 236 students, representing a 6\% response rate. Among 174 students who filled in the questionnaire in Semester 2 2018, 18 (just over 10\%) had declared disabilities. We do not know how many of the respondents in Semester 12018 had disabilities since we did not obtain detailed student data for this cohort, but we can assume the numbers will be broadly similar.

Overall, about three-quarters of students were satisfied with learning with TBL. They recognized the benefits of TBL for employability and found the approach to be inclusive. Among students with disabilities specifically, 9/18 (50\%) were satisfied with learning with TBL, 9/18 (50\%) agreed that they felt included in TBL, and 8/18 (44\%) felt that TBL was inclusive in general. Students with disabilities had more mixed views towards TBL than their peers without declared disabilities, with $66 \%$ stating that they felt included and 62\% agreeing that TBL was inclusive in general.

\subsection{Interview participants}

We carried out semi-structured interviews with four students who reported disabilities. This group included: students with specific learning difficulties; students with mental health difficulties, and one student with an autism spectrum condition. All but one of the students reported multiple disabilities, often from multiple categories. The students who took part in interviews included a mix of mature and young (under 21) students, and a mix of study subjects including business, natural science and 
clinical areas. All four students interviewed were white females, and all were UK-domiciled.

Students with disabilities found TBL team work challenging.

Compared to the population of survey respondents, the four students interviewed were all less happy with their TBL experiences. Some outright "hated" TBL.

Interview Excerpt 1: I thought I would do the interview because I did the Team Based Learning [...] and I absolutely hated it so that I wanted to make sure you got [...] another point of view. [Science student with specific learning difficulties and mental illness]

Some could see some benefits of the approach, but found that TBL, particularly the team work aspect, created challenges for their learning and for coping with their disabilities.

Interview Excerpt 2: I can see how useful the activity is for other people. I can see how they would gain from it. I can see if I was able to socialize without the overwhelming anxiety it would be useful for me too. [Science student with autism spectrum condition]

This may reflect that as students with disabilities they had less positive experiences with TBL than many of their peers, but it may also reflect that students who have something to complain about are more likely to volunteer to be interviewed.

Students reported finding it stressful to be in a situation where they were dependent on other students. This was exacerbated when they were assigned to teams with people they did not know well, due to the strategic and non-social allocation of diverse teams, which forms part of the TBL method.

Interview Excerpt 3: So we had to do a group presentation, within the group as well. It actually counted for something which made it even more scary. [Clinical student with specific learning difficulty].

Interview Excerpt 4: Especially if you don't get on with, you don't know these people and you have anxiety it's gonna plummet your score. A lot of peer pressure as well if you don't know people. [Science student with specific learning difficulties and mental illness].

For some students, depending on other students for their marks was a negative factor, for example in the tRAT, or summatively assessed group work.

Interview Excerpt 5: So you are being assessed not on your own ability but on the ability of these other people. And not even actually on their ability but whether or not they can be arsed to turn up and whether or not they can be bothered to put in the work. [Business student with specific learning difficulties and mental illness].

There were also complaints about depending on team members for shaping their learning experiences and feeling uncomfortable in an environment where collaboration was a required part of the learning activity.

Interview Excerpt 6: So being with a group of people whom I don't know is absolutely horrible. [..] These people don't know me, they don't know how I work. You 
can't sit there and try and explain to them while we're trying to do the work as well. [Science student with specific learning difficulties and mental illness].

All students interviewed (except one who was unable to work with others at all) reported finding team work stressful. They shared this in common with students with no known disability, but the stress may have created additional challenges for students who were already finding it hard to cope with the course in general. For students with social anxiety there is a clear connection between being made to work with others, and exacerbating a condition which can include extreme negative emotional responses to social interactions.

Interview Excerpt 7: I should not be forced into a situation where I feel extremely uncomfortable. It compromises my learning. So because I have anxiety and that really punches me back from even talking to anybody at all. I have social anxiety specifically. [Science student with specific learning difficulties and mental illness].

In other students, the link is less apparent, but they reported problems such as other students making them feel uncomfortable, or dominating discussions so that they (the interviewees) lost confidence.

Interview Excerpt 8: We had a really negative experience. The group I was put in had somebody that was quite overpowering. It was not just me that picked up on it, the whole group did. She completely shot all my confidence. Completely. [Clinical student with specific learning difficulty].

Interview Excerpt 9: Well you know with some of the others we'll have come to an agreement, I'll have said the agreement and then they'll have still, like, told me why I'm wrong. Like, you're in the same group as me, why are you trying to throw me under the bus? We're in the same group, and you're saying, well you're wrong. [Business student with specific learning difficulties and mental illness].

These factors of poor group dynamics had a knock-on effect of exacerbating their mental health symptoms. Respondents reported negative behaviours included asking inappropriate personal questions or making offensive remarks about the interviewees' backgrounds.

Interview Excerpt 10: And I can defend that but actually I have a processing difficulty and so therefore the length of time it's taking me to think of it and I am not good at insults, whereas quite a lot of what they're saying feel like insults. [Business student with specific learning difficulties and mental illness].

In these cases the lecturers did not intervene, possibly because the excluding behaviours happened in intra-team discussions and the facilitator was not aware, or possibly because the facilitator wished to be non-directive of classroom discussions to allow space for peer teaching and exploration of the issues.

Several students reported that they did not fit in well with their teams, perhaps partly because their disabilities made it harder for them to create successful social connections. The specific problems mentioned often related to coming from a different background to other students, for example, a mature student in a team with 18- or 
19-year-olds, again likely to be a problem for some students with or without disabilities, but perhaps creating further emotional difficulties for students who already struggled with mental health problems. The students were embarrassed to perform skills they found difficult in front of peers, such as reading or writing for a student with specific learning difficulties, or public speaking for a student with anxiety or an expressive verbal impairment.

\subsection{Benefits of team working}

Although working with other students, who were not necessarily socially compatible and sometimes were perceived as not sympathetic, caused problems for all students interviewed, some respondents perceived benefits of working in a permanent team. In some cases, they reported establishing a good working relationship as a benefit. For example, one student was able to form a team with two other students she perceived as academically able and ambitious, and the three of them supported each other to achieve highly in the module. Another student reported being lucky that at random, she was allocated to a team with students she was already friends with, and they worked together outside the timetabled sessions.

Sometimes team members were able to help work around limitations due to specific learning difficulties. For example, team members with good reading skills would read the questions out to a student with dyslexia during the RAP, meaning that she could keep up with the quiz and did not need a dedicated scribe. This informal support became a problem when a particular tutor insisted on carrying out the iRAT test in strict "exam" conditions, i.e. did not allow any talking at all during the test. In another case, students were happy with asking some other team member to record the discussion in writing and create documents to share with the rest of the class, when one student was uncomfortable with writing in front of other people due to her dysgraphia.

Reasonable adjustments for disabilities were sometimes compromised in TBL. In terms of specific adjustments and accommodations for specific learning difficulties, students reported that adjustments were less readily available in TBL than in other learning approaches. For example, reading materials for the TBL application exercises were not provided in accessible formats, such as coloured paper or readable fonts (ARU, 2020b), although in other parts of their courses the students would expect such accommodations. Students usually printed out their own materials in a format that worked for their reading difficulties but found that in TBL, materials were not usually made available online in advance of the face-to-face learning activity, meaning that they were not able to use this strategy.

Interview Excerpt 11: [Pre-class independent learning] was all right. Because we got given information, you know, we get lots of different ways of preparing in videos, texts, you'll get reading. We get given lots of sources, but in the classroom we're not given that. [...] I tend to print it out on coloured paper or things like that. So I can prepare it for myself. [...] We wasn't already asked to bring anything in, so it tends to 
be, we get given the stuff in the classroom. [...] It was all on paper. It is not really any point in taking laptops and stuff, because it was all stuff that he was giving us and it wasn't accessible to us. [Science student with specific learning difficulties and mental illness].

Interview Excerpt 12: We obviously print all the stuff, I' $m$ a bit, I like a bit of paper. I have all my notes printed and like the slides printed for the lecture so that I can just make notes next to them which makes my life a lot easier. [Clinical student with specific learning difficulty].

Students might be entitled to support from a scribe or reader during an exam, but there was no formal mechanism to support them with reading the iRAT questions or writing down findings during application exercises.

Interview Excerpt 13: I get extra time in exams. I get 25 percent extra time which I think it means summative extra time. I get that in all formal assessment. But I do not get it in my mid-term assessment. I should get access to a computer to do my exams with. I can get access to them in formal exams, but not in midterm assessments. [Business student with specific learning difficulties and mental illness].

A theme that was repeated for several interviews was difficulties caused by adhoc seating arrangements. When TBL teams are assigned in the first session, the lecturer/facilitator may allocate each team to a table arbitrarily, and teams will generally sit in the same place for each subsequent class. For some students simply not having a choice of seating (unlike the situation in a non-TBL setting where students can generally sit wherever they choose) provoked anxiety. For others, they found that a particular location in the room was more conducive to learning, and did not feel able to object if they were told to move away from that position.

Interview Excerpt 14: Because when I go into the normal lessons I can sit right at the front or in the middle. It is my choice. Whereas you know, put in a group, the group sort of decides where they want to go. [Science student with specific learning difficulties and mental illness].

For example, a student who experienced attention deficits resulting from her specific learning difficulty (dyspraxia) found that in a TBL classroom she was frequently distracted by the other students and movements in the room, and would have preferred to be able to sit near the front where only the lecturer was in her line of sight.

Interview Excerpt 15: But if you're not sat in the right place, you can't see the screen properly, you can't hear him properly. So I was quite often faced away from him, I can't see him. And also because of the dyspraxia I get distracted easily by movements. I can see everybody. It is actually really [more] distracting than sitting in lines. [Science student with specific learning difficulties and mental illness].

Others were anxious if they could not see a clear route to the exit if they could not see what was going on behind them, or if they had to sit too physically close to other students. 
Interview Excerpt 16: I won't sit anywhere except the first front row and I won't sit with people near me. So at least one space. So I always put my bag on the chair next to me and I try to sit on the end. Usually the end nearest the door or easiest exit. I prefer more than one space if I have someone sat the other side of my bag it can make me very edgy. [Science student with autism spectrum condition].

Although none of the students interviewed had hearing impairments, we know that many deaf students also need to sit in a position where they can see the lecturer well enough to lip-read, and where background noise is minimized. It is likely that students in this situation would also struggle if they had to move to a table based on random team numbers.

In principle, students could have asked for reasonable adjustments regarding seating, provision of formatted materials etc. However, several of the students referred to not wanting to disclose all of their conditions to their team members.

Interview Excerpt 17: You can't sit there and try and explain to them while we're trying to do the work as well. There was a lot of pressure as well in like a very small space of time. I think that sometimes people do not realize that it can be extremely negative to people like me. [Science student with specific learning difficulties and mental illness].

Generally, the students seemed happy to make reference to their specific learning difficulties and neurodivergence.

Interview Excerpt 18: We all know where people are struggling and can help each other out. [Clinical student with specific learning difficulty].

Interview Excerpt 19: I mean you get, who's going to write it, it was always like, well, I don't want to write it because I've got dyslexia. My writing is awful, you can't read it. [Science student with specific learning difficulties and mental illness].

Interview Excerpt 20: I am diagnosed Asperger's. In day-to-day terms, I prefer to use the term autism, as more people understand it. It is just easier for me. [Science student with autism spectrum condition]

However, they felt that mental illnesses were stigmatized and they did not want team mates to know about their mental health issues, particularly when they were put into teams with people they did not know well because of how teams are formed strategically in TBL.

Interview Excerpt 21: Actually, while I am very very anxious about people finding out about the mental health condition, I don't care about, you can find out I'm dyslexic, I talk about it openly. I don't talk about mental health openly. I've had discrimination on that basis before. [Business student with specific learning difficulties and mental illness].

Interview Excerpt 22: I was moved twice because I physically said the people who I was with was making me feel extremely uncomfortable. So very immature and they do things which I don't approve of. I did try right at the beginning to join in and I was just ignored and not listened to. [...] So when I did get moved into another group 
who were quite nice. I mean it was a bit better than the previous groups but because I have got, as I said, the anxiety and struggling as it is normally, it's still not very good. These people don't know me and, as I said, there's no time to get to know each other. It's just get in, do your work and leave. I don't see these people outside so... [Science student with specific learning difficulties and mental illness].

In a lecture situation, students normally only interact with the lecturer and have avenues which allow them to mention a requested adjustment in confidence so that the lecturer can accommodate them. Students also have the option of going through the formal route of declaring a disability and working with the Disability and Dyslexia Service to prepare a Statement of Reasonable Adjustment (SoRA), which is then disclosed to the lecturer ahead of the teaching period.

Interview Excerpt 23: I know ARU actually is very very good on mental health. It is certainly very good at faculty level. The lecturers that I have specifically mentioned it to, could be very very good. It's statemented now. So I have never had any type of discrimination in the institution. [Business student with specific learning difficulties and mental illness].

For students learning with TBL, these options are still available, but it may be more difficult to communicate confidentially with the lecturer and to apply the adjustments without singling out a particular student in a way that would make them uncomfortably visible to the team or the whole class.

Interview Excerpt 24: I'm not confident enough to say, please go back at all. I don't like bringing attention to myself at all. [Clinical student with specific learning difficulty].

One example where a reasonable adjustment was successfully applied was in the case of a student whose autism spectrum condition meant that she had extreme difficulty in participating in group work. This student had declared her disability to the Disability and Dyslexia Service and had a SoRA stating that she should not be expected to work with groups. The lecturer was therefore aware of the student's needs and made the adjustment of allowing her to constitute a "team" on her own, so that she could take part in most elements of TBL learning activities, without ever having to work directly with other students, and she was assessed for the team elements of the module as a single-person team.

Interview Excerpt 25: [The tutor] accepted very quickly without much fight that I was not going to work with the other people and I was going to sit on my own in this particular table and that was fine by me. When we did the individual group test they actually, cause they had these like scratch cards prepared. They named me as group thirteen and gave me a scratch card for the group thing. [..] but they brought extra resources for me. [Science student with autism spectrum condition].

This reasonable adjustment was workable because the student in question was highly academically able. She felt confident to carry out tasks intended for a team of five or more people to a satisfactory standard on her own. 
Interview Excerpt 26: So if we're doing any kind of group project I am more than happy and capable of taking on the entire group project alone and doing that and I prefer that, honestly I think I can do it better than most people anyway. [Science student with autism spectrum condition].

\subsection{Problems with course organization}

For several of the students, the strategies they would normally apply to achieve successful learning with their disabilities were disrupted by TBL. For example, a student who would usually take extra time to go over material from a taught session such as a lecture, and make her own notes, was unable to do this in TBL units. In her course, lectures were used in place of independent pre-session learning, and these were timetabled too close to the face-to-face session. Further, there was no time allotted for independently going over the work after the end of the session, because the in-class application exercises are seen as the final stage of consolidating learning.

Interview Excerpt 27: Sometimes I think [the TBL sessions] are a bit of waste of our time. So today, I have just come, before I came up here from my bioscience lecture. My TBL for it is this afternoon. We've had no time to revise. I mean what is the point in doing a quiz to check what we have learnt, when we have not had the time to learn it. [...]

That's a lot of information in hour and a half to then go and have to try and process it whilst, so I have got this, and another two hour lecture which is completely different and then go into a lecture again. It is a lot of work. [Clinical student with specific learning difficulty].

Another student also experienced challenges when in-class TBL sessions were timetabled on the same day as lectures from other modules.

Interview Excerpt 28: I find [the application activities] tricky because they normally, the way our timetabling is, we've got a lecture in the morning and the seminar in the afternoon. So for me that is not enough time in between. It is working on short-term memory which I don't have, I don't have it with dyslexia. It makes the days very very long, which when I am not mentally well, I can't do it. [Business student with specific learning difficulties and mental illness].

A student whose disabilities presented challenges with time management and executive function (the ability to plan actions with a series of complex steps) could normally "get away with" leaving most of the work for a module or project until near the end of the teaching period, but the regular structure of TBL, with multiple lowstakes assessments, challenged this strategy.

Interview Excerpt 29: In fact the iRAT and tRAT test was not difficult but I have really, really poor time management. Actually getting round to watching the video lectures and reading the chapters before the lectures. It didn't happen that often. I often did them afterwards but that meant I was going in to the test unprepared. [Science student with autism spectrum condition]. 
Conversely, a student who found project assessment deadlines anxiety-provoking controlled her anxiety by starting each piece of work well in advance, leaving plenty of time, and planning her time in detail. She was not able to do this when she was working with a team, who did not share her anxiety condition and usually left things to the last minute.

Interview Excerpt 30: As a disabled student, I have to plan my work very very carefully. I have to plan when I am going to do the work, when I am going to complete it. I do have caring responsibilities as well. [...] But if I do a little bit each week and I can plan and over-structure it that is fine. [...] So it means that it is a lot harder to plan with TBL than it is with any other learning. Planning no matter what your condition is as a disabled student, that's your key to actually coping and TBL undermines your ability to plan and it can have a knock-on effect to all the other subjects. [...]

They did everything last minute. I can't do that. If I do that, I will fail. And that's just on dyslexia, if I do that, I will fail. That's not the other one, that's not mental health at all, if I leave everything to the last minute, as a dyslexic I will fail. [Business student with specific learning difficulties and mental illness].

\section{Discussion}

\subsection{Interpretations}

We carried out interviews with four students with different and in most cases multiple disabilities. The student who had a specific learning difficulty only, with no accompanying mental health condition, expressed the most positive views of TBL, although it was not without its problems. For students who had any kind of mental health condition, TBL was seen as a source of stress, and the stress made it harder for them to learn.

All four students found their relatively unstructured experiences with TBL disrupted some of their strategies for successful learning with a disability. In a didactic classroom, the lecturer provides the content and has both the responsibility and hopefully the skills to make sure that all material is available in accessible formats. When students are co-creating and applying their conceptual knowledge in perhaps unpredicted ways, some materials generated by students on the fly may not be accessible. For example, scribbled notes on a flip chart may not be easy to read for students with special learning difficulty, especially not at speed. Equally, because most of the application of knowledge takes place in a face-to-face session, students who might take extra time over consolidating their learning independently have much more limited time available to do so, as the class as a whole will quickly move on to the next topic or exercise.

Students with disabilities had a very similar set of complaints to students without disabilities about the difficulties of working with peers they did not know well. It could be interpreted that students who had a mental health condition blamed their condition 
when team dynamics were challenging, whereas other students who had similar problems located the cause in other students' poor behaviours. Some of the students did report that teams developed their patterns of working as they got to know each other. However this was not a major theme; students' impressions were dominated by the view that if they started out with team problems, those problems often persisted throughout the module and continued to disrupt learning and promote anxiety.

Several students mentioned that they would prefer being allowed to work with their friends, again an attitude they shared with their non-disabled peers. Experience from TBL practice indicates that socially formed teams often function poorly; some students may be excluded, or interpersonal difficulties from the team members' social lives may spill over into the classroom. Because of these experiences, It is one of the principles of TBL that teams are strategically assigned to promote diversity (Michaelsen, Davidson, \& Major, 2014; Michaelsen, Knight \& Fink, 2004; Sibley \& Ostafichuk, 2014). If students simply work with people they are already socially connected to, they will not be exposed to a wide range of opinions and experiences. Furthermore, teams, where all members are struggling academically, may lack the skills to support and peer teach each other, and teams, where all members are high performers, are likely to become over-competitive.

Teaching communication, group working and to some extent negotiation and conflict resolution skills is an explicit aim of the TBL method (Eksteen, 2019; Michaelsen, Knight \& Fink, L. D., 2004; Sibley \& Ostafichuk, 2014). Interestingly, all students interviewed reported that they did not need to learn how to work in teams, as they already had work experience of team work (again, except for the student whose disability meant she was unable to work in groups at all). This included returning students who had already experienced professional careers before taking a degree, and young students who had part-time jobs to help fund their studies and living costs. For these students, the team working as part of TBL felt artificial and not representative of the team working they experienced in the workplace. One mentioned that she was perfectly capable of working with difficult people in a highflying career, but nevertheless found TBL team projects exceptionally stressful, partly due to the assessment element. Another student explained that she was able to cope with difficulties with group work while at work, albeit with difficulty, but that in her learning she expected to be able to relax and feel comfortable. She identified a difference between being paid to do a job even if she found some parts of it challenging, versus paying for an education, which should be in her interest.

\subsection{Conclusions and Recommendations}

What emerges from the interviews is that there are some difficulties which are inherent to TBL and would be difficult to change without giving up some of its fundamental principles, but for most difficulties, TBL practice could be adapted to be more inclusive of learners with disabilities. 
For example, as with any learning and teaching approach, it should be an expectation that materials are provided in advance of in-class sessions so that students can reformat them as appropriate and take extra time if necessary to process the information. However, when we carried out an informal survey of TBL modules on the virtual learning environment, we saw very little in the way of materials available electronically; the pre-session independent work was uploaded, but the in-class application exercises were not. It is understandable, that lecturers may wish to leave space for the TBL discussions to be openly facilitated rather than highly pre-structured, but the structure of each unit is decided in advance and any reading expected from the students during application exercises should be made available just as would be normal practice for a seminar.

Similarly, it is important in TBL for tutors to assign students to teams strategically to promote diversity. However, it would be a reasonable adjustment for a disabled student to be joined by a familiar person in the team, who has been supporting these students to overcome some of the challenges of team work. In rare cases, as was the case with the student on the autism spectrum, a lecturer may need to consider a team of "one” for this student as long as the student can take part in class and thus engage passively with other teams and attends. Further helpful support would be to allow a team member to read out the RAT questions and application exercises to support students with reading difficulties and to avoid assigning writing tasks to students with writing difficulties and social anxiety.

Group and team work can be challenging for students irrespective of if it is part of TBL or not. Therefore great care has to be taken to scaffold the group and team formation process from induction and learning agreements to processes promoting trust, accountability and positive team cohesion. This scaffolding is especially important for teams with students with disabilities or specific learning difficulties.

Activities at the beginning of team formation can involve requiring the team to agree on time management and learning patterns to support students who need a more structured study approach. Within a class, the teacher can manage the timing of activities to ensure students with disabilities are not rushed and providing them with the (extra) time they may need.

It is usually desirable for teams to sit around tables to promote discussion and interaction. It is not necessary for groups to be sent to sit at arbitrarily assigned tables in the classroom during the first session. If teams are formed in advance, tutors can make team membership lists available electronically, and allow students to request to sit in a particular location in the room. This would also solve the problem reported by one of the students with anxiety, where the situation of everybody crowding round a list of names to work out which table to sit at was panic-inducing.

It goes without saying that teamwork is more realistic if the learning process includes application exercises and assessments set in real-life contexts. 
Overall we found that with some adjustments to teaching and facilitating TBL students with disabilities or specific learning difficulties can be accommodated and their challenges can be addressed.

\section{References}

Active Collaborative Learning. (2019). Scaling Up Active Collaborative Learning for Student Success. Project website. Retrieved from https://aclproject.org.uk

ARU (2017). Equality, Diversity and Inclusion at our University. Annual Report. Anglia Ruskin University. Retrieved

from https://web.anglia.ac.uk/anet/student_services/public/AngliaRuskinReport_2017_AW_AC CESSIBLE.pdf

ARU (2018). Student Snapshots. Anglia Ruskin University. Retrieved from https://aru.ac.uk/aboutus/equality-diversity-and-inclusion/equality-diversity-and-inclusion-for-students/aru-studentsnapshots.

ARU (2020). Disability Support. Anglia Ruskin University. Retrieved from https://aru.ac.uk/studentlife/support-and-facilities/study-skills/disability-support.

ARU (2020b). Inclusive Practices. Anglia Ruskin University. Retrieved from https://aru.ac.uk/aboutus/equality-diversity-and-inclusion/equality-diversity-and-inclusion-for-students/inclusivepractices.

Berkson, R., \& Richter, U.M. (2019). Can Active Collaborative Learning Improve Equality? The European Conference on Education 2019 Official Conference Proceedings. Retrieved from https://papers.iafor.org/submission51859/

Berkson, R.G., \& Richter, U.M. (2020). Barriers to scaling up active collaborative learning. In S. Pratt-Adams, U.M. Richter \& M. Warnes (Eds.), Innovations in Active Learning in Higher Education, Ch 7. Anglia Ruskin University (in press).

Chenail, R. J. (2009). Interviewing the Investigator: Strategies for Addressing Instrumentation and Researcher Bias Concerns in Qualitative Research. The Qualitative Report, 13(4), 14-21. Retrieved from https://nsuworks.nova.edu/tqr/vol13/iss4/14/

Dearnley, Ch., Rhodes, Ch., Roberts, P., Williams, P., \& Prenton, S. (2018). Team based learning in nursing and midwifery higher education; a systematic review of the evidence for change. Nurse Education Today, 60, 75-83. Retrieved from http://dx.doi.org/10.1016/j.nedt.2017.09.012

Eksteen, M.J. (2019). Does team-based learning develop essential generic skills in pharmacy students? South African Journal of Higher Education, 33(1). http://dx.doi.org//10.20853/33-11332

Haidet, P., Kubitz, K., \& McCormack, W. T. (2014). Analysis of the team-based learning literature: TBL comes of age. Journal on Excellence in College Teaching, 25(3-4), 303-333. Retrieved from https://www.ncbi.nlm.nih.gov/pmc/articles/PMC4643940/

Hefce. (2018). Differences in student outcomes. The effect of student characteristics. Data Analysis report March 2018/05. Retrieved from https://dera.ioe.ac.uk/31412/1/HEFCE2017_05\%20.pdf

HM Government. (2017). Industrial Strategy. Building a Britain fit for the future. UK Government White Paper. Retrieved from https://assets.publishing.service.gov.uk/government/uploads/ system/uploads/attachment_data/file/664563/industrial-strategy-white-paper-web-readyversion.pdf

Kent, S., Wanzek, J., Swanson, E.A., \& Vaughn, S. (2015). Team-Based Learning for Students with High-Incidence Disabilities in High School Social Studies Classrooms. Learning Disabilities Research \& Practice, 30(1), 3-14. Retrieved from https://onlinelibrary.wiley.com/doi/abs/10.1111/ldrp.12048 
Koles, P.G., Stolfi, A., Borges, N.J., Nelson S., \& Parmelee, D.X. (2010). The impact of team-based learning on medical students' academic performance. Academic Medicine: Journal of the Association of American Medical Colleges, 85(11), 1739-1745. http://dx.doi.org/10.1097/ACM.0b013e3181f52bed

Michaelsen, L. K., Davidson, N., \& Major, C. H. (2014). Team-based learning practices and principles in comparison with cooperative learning and problem-based learning. Journal on Excellence in College Teaching, 25(3-4), 57-84. Retrieved from https://www.lhthompson.com/ uploads/4/2/1/1/42117203/team_based_learning_-_group_work.pdf

Michaelsen, L. K., Knight, A. B., \& Fink, L. D. (2004). Team-based learning: A transformative use of small groups in higher education. Sterling, VA: Stylus.

McNeil, J., Borg, M., Kennedy, E., Cui, V., Puntha, H., Rashid, Z., Churchill, T., Howitt, E. and Trivedy, K., (2019a). SCALE-UP Handbook 2019-20 (3rd ed). Centre for Academic Development and Quality, Nottingham Trent University. Retrieved from https://www.ntu.ac.uk/_data/assets/pdf_file/0033/906927/FINAL-SCALE-UPHandbook-2019-20.pdf

McNeil, J., Borg, M., Kerrigan, M., Waller, S., Richter, U., Berkson, R., Tweddell, S., \& McCarter, R. (2019b). Addressing barriers to student success. Scaling up Active Collaborative Learning for Student Success. Final Report, 28 March 2019, Updated 28 October 2019. Retrieved from https:/aclproject.org.uk/wp-content/uploads/2019/07/NTU-ABSS-Final-Report-revised-Oct2019.pdf

OECD. (2019). OECD Future of Education and Skills 2030. OECD Learning Compass 2030. A Series of Concept Notes. OECD. Retrieved from http://www.oecd.org/education/2030project/contact/OECD_Learning_Compass_2030_Concept_Note_Series.pdf.

Office for Students. (2019a). Addressing Barriers to Student Success programme. Retrieved from https://www.officeforstudents.org.uk/advice-and-guidance/promoting-equalopportunities/addressing-barriers-to-student-success-programme/

Office for Students. (2019b). Beyond the bare minimum: Are universities and colleges doing enough for disabled students? OfS Insight Brief 4. Retrieved from https://www.officeforstudents.org.uk/publications/beyond-the-bare-minimum-areuniversities-and-colleges-doing-enough-for-disabled-students/\#participation

Roulston, K., \& Shelton, St. A. (2015). Reconceptualizing Bias in Teaching Qualitative Research Methods. Qualitative Inquiry, 21(4), 332-342. Retrieved from https://journals.sagepub.com/doi/10.1177/1077800414563803

Sangwan, P., \& Sangwan, S. (2011). Inclusive Education: A Developmental Approach in Special Education. Journal of Indian Education, 36(4), 18-32. Retrieved from http://www.ncert.nic.in/ publication/journals/pdf_files/iea/JIE_FEB2011.pdf\#page $=20$

Sibley, J., \& Ostafichuk, P. (2014). Getting Started with Team-Based Learning. Sterling, VA, USA: Stylus.

Sisk, R. J. (2011). Team-based learning: systematic research review. Journal of Nursing Education, 50(12), 665-669. Retrieved from https://pubmed.ncbi.nlm.nih.gov/22007709/

Vaccaro, A., Daly-Cano, M., \& Newman, B. M. (2015). A sense of belonging among college students with disabilities: An emergent theoretical model. Journal of College Student

Development, 56(7), 670-686. Retrieved from https://muse.jhu.edu/article/597267

Vaughn, S., Danielson, L., Zumeta, R., \& Holdheide, L. (2015). Deeper Learning for Students with Disabilities. Students at the Center. Deeper Learning Research Series. Boston, MA: Jobs for the Future. Retrieved from https://files.eric.ed.gov/fulltext/ED560790.pdf 
Wanzek, J., Vaughn, S., Kent, S.C., Swanson, E.A., Roberts, G., Haynes, M., \& Solis, M. (2014). The Effects of Team-Based Learning on Social Studies Knowledge Acquisition in High School. Journal of Research on Educational Effectiveness. 7(2), 183-204. Retrieved from https://www.tandfonline.com/doi/abs/10.1080/19345747.2013.836765

Williams, M., Pollard, E., Helena Takala, H., \& Houghton, A-M. (2019). Review of Support for Disabled Students in Higher Education in England. Report to the Office for Students by the Institute for Employment Studies and Researching Equity, Access and Participation. IES Report. Institute for Employment Studies and Researching Equity, Access and Participation. Retrieved from https:/www.officeforstudents.org.uk/media/a8152716-870b-47f28045-.fc30e8e599e5/review-of-support-for-disabled-students-in-higher-education-inengland.pdf

World Economic Forum. (2018). The Future of Jobs 2018. Insight Report. Centre for the New Economy and Society. Retrieved from: http://www3.weforum.org/docs/WEF_Future_of_Jobs_ 2018.pdf

World Economic Forum. (2018). The Future of Jobs 2018. Insight Report. Centre for the New Economy and Society. Retrieved from http://www3.weforum.org/docs/WEF_Future_of_Jobs_2018.pdf. 